\title{
Information and Communication Technology (ICT) in Knowledge Sharing Practices: Needs for the Establishment of Repository
}

\author{
Mohd Norhadi Muda ${ }^{1}$ \\ Zawiyah M. Yusof ${ }^{2}$ \\ ${ }^{1}$ Faculty of Technology \& Information Science, National University of Malaysia, 43600 Bangi, Selangor, Malaysia \\ norhadimuda@gmail.com \\ ${ }^{2}$ Faculty of Technology \& Information Science, National University of Malaysia, 43600 Bangi, Selangor, Malaysia \\ zmy@ftsm.ukm.my
}

\section{Doi:10.5901/mjss.2015.v6n5s1p69}

\begin{abstract}
Higher Education Institution (IHL) is an organization that promotes knowledge sharing practices for teaching and learning and research. Not much research has been carried out on the use of Information and Communication Technology (ICT) in knowledge sharing in the education sector to form repository which in turn can help lecturers to acquire knowledge for teaching purposes. The objective of this research is to find out the ICT factors influence to knowledge sharing practices among the lecturers and the impact of creating repositories on the performance of teaching and innovation among lectures. A total of six hypotheses are put forward for this purpose. This study uses a quantitative approach as instrument to collect data from questionnaire. A total of 170 lecturers were selected as respondents from the Faculty which offer ICT program from four universities in the Klang Valley were involved in this study. The result shows that ICT management, Knowledge Management Systems and ICT Infrastructure has significantly influenced the practice of knowledge sharing; knowledge sharing practices have significantly shaped the repository, the performance of teaching and teaching innovation has a significant relationship to the re-use of knowledge repositories. The results of the study can serve as a guide to IHL in designing and ascertain direction ICT development of knowledge-sharing practices.
\end{abstract}

Keywords: Knowledge sharing, ICT factor, repository, teaching performance, teaching innovation

\section{Introduction}

Higher Education Institutions (IHLS) need to use Information and Communication Technology (ICT) for the planning and the objective of knowledge sharing practices (Agarwal et al., 2012). The practice of knowledge sharing is important to preserve knowledge apart from being a source of reference for the purposes of teaching and learning, research and collaboration (Iqbal et al., 2011). As such, for this purpose, ICT is needed to support and manage knowledge effectively and also to encourage the sharing of knowledge, particularly among the lecturers. Lecturers need knowledge to fulfill their responsibility as educators (Kiran et al., 2013) apart from providing a conducive teaching and learning environment (Howell \& Annansingh, 2013). As such, for the purpose of acquiring this knowledge, the repository is required in IHLs as storage for knowledge (Beatrice et al., 2010). Therefore, the IHLs should have a framework of knowledge sharing practices among the lecturers. Consequently, there is a need to have a study on ICT factors which affect knowledge sharing practices. Hence, this will lead to the establishment of a repository that can be used to increase the performance and innovation of teaching in institution of higher learning $(\mathrm{IHLS})$.

\section{Problem Statement}

This study is based on a number of loopholes on the sharing of knowledge in IHLS. Past studies on knowledge sharing usually focus on community practices (Nistor et al., 2012), the prediction of intention (Rahab \& Wahyuni, 2013), behavioral (Azlyn et al., 2011), practice (Ayalew, et al, 2010), ethics (Patel \& Ragsdell, 2011) and education cooperation (Li et al., 2013). There were no studies which focus on ICT factors regarding the sharing of knowledge in universities, which eventually led to the establishment of the repository. This study was consistent with the proposal from Nor Ashmiza (2012) to carry out study on knowledge sharing which take into account technological factors. Furthermore, studies on the establishment of repositories in IHLS just focused on the aspects of the requirements and advantages of the repositories 
(Naiwen \& Xin, 2012) and the needs of communication which interconnect repositories in IHLs (Alhawary et al., 2011). There were no studies on knowledge sharing initiatives that led to the establishment of repositories. Repository of knowledge is important because the standard of an innovation and performance of lectures depend on existing knowledge (Kumar \& Rose, 2012). In addition, the knowledge repository can overcome the problem of withdrawal and transfer of educators, which resulted in the loss of trainers in organization and also the loss of intellectual property as academicians bring together their skills and knowledge.

Although past studies had make ICT factors part of their investigation (Cheng et al, 2008; Sulisworo 2012) but the studies did not determine the aspects of ICT management. Instead they only focused on ICT application and infrastructure. ICT management should be focused because this aspect is able to manage and its applications and infrastructure operations in IHLS.

IHLS always strive to produce graduates who meet the skills required by the industry. Therefore lecturers should play an increasing role in their teaching performance (Doctor \& Ramachandran, 2008) and innovation (Wang, 2009) through the re-use of knowledge repositories in IHLS.

\section{Objective}

The objective of this paper is to investigate influence ICT factors for knowledge sharing initiative in Public Institution of Higher Learning (IHLs) in Malaysia which eventually establish a knowledge repository and the reuse of knowledge from repository can improve the teaching performance and innovation among lecturers

\section{Literature Review}

\subsection{Knowledge Sharing}

Knowledge is defined as a combination of experience, values, information and understanding of the individual. Knowledge can be uttered, concluded, written, drawn and compiled to form the experience and new knowledge (Nonaka, 2006) in various formats such as documents, images, sound and video. This knowledge can be shared through a process of exchanging experience, expertise, events and thoughts that are agreed upon by the provider and recipient of knowledge (Shah et al., 2009)). Sharing knowledge is also an important process in knowledge management. Sharing knowledge is important to improve performance, save time and operating costs, encourage employees to be creative (Iskandar et al. 2011) and increased the level of knowledge application especially in the teaching and learning process (Hafiza \& Dang, 2012). Hence the practice of sharing knowledge is important in helping organization's objectives. In this study, sharing knowledge is referred to sharing notes, tests, quizzes and projects among lecturers in universities.

\subsection{The Information and Communication Technology (ICT) Factors.}

Modern economy requires knowledge sharing activities to be as an important source of practice which is supported by the use of ICT. This is because ICT can reduce barriers in knowledge sharing activities and it also could save time (Casimir et al., 2012). Past researchers agreed that ICT is one of the factors that influence knowledge sharing activities among workers which is also cross geographical boundaries and functions of parts. Grace's study (2009) has found that knowledge sharing activities using ICT can increase the rate of knowledge sharing among educators in educational institutions. According to Fadilah (2013) the activity can also narrow down the knowledge gap. Therefore, organizations which manage ICT systematically is able to make the organization more competitive and have added advantage (Raab et al., 2014). However, the existence of ICT is not necessarily means IHLs staff are practicing knowledge because ICT is just a driving factor. ICT factors in this study refer to the availability of software, hardware and management. Software is a set of instructions that allow the computer to operate. The software is divided into software applications and system software. This study refers to the application system of knowledge management system (KMS). KMS helps knowledge sharing activities through the process of storing, distributing and added value to the knowledge (Dukiü \& Kozina, 2012) either formally or otherwise (Shahrinaz 2010). Computer equipment is a computer component that helps the computer to operate. The components are computer equipment and network. Thus, the role of computer software and hardware are part of ICT's preparation and infrastructure that support the implementation of knowledge sharing (Hafiza \& Dang, 2012). Knowledge Management Systems (KMS), infrastructure and ICT management are the main focus carried out in this study. 


\subsubsection{Information and Communications Technology (ICT) Management}

ICT management is part of the management aspects of the organization trying to achieve its vision and mission. Weak ICT management contributes to the difficulty of achieving the goals and performance of the organization (Norashikin, 2013). Organizations management need to understand which aspects of ICT affect the operation of the organization thus finding ways to put more emphasize consistently on ICT management such as planning, maintaining, financing and managing human resource. Studies on ICT management in the public sector emphasize the performance, management reporting, resource management, risk management, strategic alignment and delivering value ((Radovanović, et al., 2011). One of the main sources of ICT in organization is the knowledge. Resources must be managed accordingly to ensure that these organizations are preserved. Therefore, consistent ICT management enables the management to provide an effective ICT infrastructure for effective knowledge sharing activities (Han \& Anantatmula, 2007). An organized ICT management can have an impact on improving the quality of IT services as well as reducing costs. Apart from that, changes in knowledge management based on the current needs which were highlighted since 1970s requires innovation and ICT to support their knowledge to make it relevant all the time. Thus ICT management is necessary to manage knowledge so that it can be maintained and utilized optimally.

\subsubsection{Information and Communication Technology (ICT) Infrastructure}

ICT infrastructure refers to the existence of physical facilities and services that support the use and the sharing of computerized information systems in an organization. It covers five aspects, namely; hardware, software, network and communications facilities, databases and management staff (Fadillah, 2013). Provisions of ICT infrastructure facilities as a whole play an important role in the process of sharing knowledge and accelerate the pace of knowledge creation and help in the process of creating a repository organization. Physical facilities such as networking, software, and hardware, and internet facility are the ICT infrastructure that supports knowledge sharing activities (Noorazah, 2013). This facility enables effective communication between employees within organization. ICT infrastructure facilities could increase the use of software and hardware in the sharing of knowledge as well as helping employees to create, transfer and share knowledge effectively. In the context of higher education, the provision of ICT facilities can increase the interest for lecturers to share knowledge (Kant \& Singh, 2008). Reviews from Phang \& Foong (2010) proved a good ICT infrastructure can help support the process of knowledge sharing. However, the provision of ICT infrastructure incurs high cost.

\subsubsection{Knowledge Management System (KMS)}

The effective knowledge-sharing activities need a structured application system (French, 2010). KMS is a system that can increase the effectiveness of knowledge management and is a sort of knowledge sharing activities. KMS is part of the information system to increase the effectiveness of knowledge management in organization, especially knowledgesharing activities (Busaidi, 2013) apart from coordinating the creating, sharing, storing and disseminating of knowledge in a systematic manner. Aspects that should be taken into account in the KMS are function, interface, database, access and security which must be followed according to the requirements and needs of IHLs to ensure the use of KMS is at optimal level. Apart from that, the quality and standard of stored knowledge should be taken into account. If these aspects are addressed, KMS can encourage and raise awareness to lecturers to share knowledge (Zheng, 2012) which consequently can help to increase organizational performance. In this study, KMS refers to a system that manages knowledge as a medium and to facilitate lecturers to share underlying knowledge. The focus of this study is the KMS and the effectiveness of the system such as interfaces, functions and KMS training.

\subsection{Knowledge Repository}

Knowledge repository is a warehouse for storing knowledge that can be used as a strategic resource (Naiwen \& Xin, 2012; Sulisworo, 2012). Organizations, especially IHL, should develope knowledge repositories to encourage knowledgesharing practices among the lecturers who either has limited or a variety of knowledge (Choubey, 2011). The repository can gather knowledge from the lecturers (Beatrice et al., 2010) through knowledge sharing initiatives. The resource knowledge can be accessed and re-used for the purpose of learning, teaching, research and publication (Du et al., 2012). At the same time, the establishment of repositories require support from the management especially for the coordinating and managing purpose. It is aimed to ensure the organization is willing to face current challenges, particularly changes in 
the administration and their organizational direction.

\subsection{Teaching Performance}

Past studies have shown that performance is an important element in helping to organization to perform better by using knowledge as a reference (Nesheim \& Gressgård, 2014). However there were no studies that explored the effects on the formation of the repository towards lecturer's performance in IHLs. According to (Islam et al.,2013) studies suggest that the relationship between knowledge re-use repository because it can improve the performance of teaching. One of the areas that should be focused is teaching performance in IHLS. Teaching is carried out by lecturers for the students' learning process. Reigeluth \& Carr-Chellman (2009) describes teaching is a process of preparing and planning of activities to help students gain knowledge and develop skills to generate learning process. Therefore, the teaching process requires careful planning, apart from having a clear awareness and intention (Noor Hisham, 2011). However, that according to Beyer, (2011) adequate knowledge in the subjects taught can help improve the teaching process. The focus is on identifying and adjusting the pace and content to suit students' needs, and also to provide opportunities for students to practice using a high-level thinking skills

\subsection{Innovation in Teaching}

The creation of a new innovation requires knowledge as a source of reference. Hence knowledge sharing practices can provide the knowledge to create innovation new ideas and new strategies apart from a new approach in solving the problem in the organization. This is supported by past researchers which recognized innovation as an important source of knowledge to the work process and the key to the success of an organization (Oliveira et al., 2011). Innovation in education sector can help academicians to be more knowledgeable and productive (Hannay, 2013). This is because one of the problems that hinder the success of IHLs is the lack of innovation in teaching. In addition, teaching innovation can help lecturers using new approaches in the teaching process, increase creativity in teaching process resulting in learning process becomes easier (Wang, 2009). Innovation in teaching is a creative reformation that involves new methods or means used by educators to achieve the objectives of teaching (Yahya \& Lailinanita, 2012). Hence the teaching innovation brought by the lecturer can increase the value added in producing graduates.

\section{Theoretical Framework}

The theoretical framework used to develop the conceptual framework in this study is the technology, organization and environment (TOE) framework which was introduced by Tornatzky and Fleischer in 1990 and adapted from the 'Theory of Organizational Contingencies'. The TOE framework is suitable to use in research based on organizations (Arpaci et al., 2012) and performance indicators (Savita et al., 2012). This framework has three contexts: technology, organizational and environmental, as shown in Figure 1.1. The technology context includes infrastructure, processes, techniques and the latest ICT expertise (Tornatzky \& Fleischer, 1990) that emphasise on making decisions related to ICT (Tung \& Lai, 2013). While the organizational context includes size, scope, centralization, official function, management structure, quality of human resources, decision-making methods, communication, intentions, planning and structure (Tornatzky \& Fleischer, 1990; Lippert \& Ph, 2006) that leans towards organizational characteristics (Arpaci et al., 2012). The environmental context comprises firms, suppliers, employees, customers, competitors and government agencies (Tornatzky \& Fleischer, 1990).

\section{Knowledge Sharing Conceptual Framework}

Analysis on past models and knowledge-sharing frameworks has found that the framework emphasises on two factors. Firstly, the need to develop repository, and secondly, the different factors that influence knowledge sharing initiatives. Both factors provide the basis for developing the conceptual framework and this paper is using approach Fadillah et al. (2011) and Mohd Bakhari, (2010). The approach to the conceptual framework development is shown in Figure 1.1. The input which represent the factors influence knowledge sharing are organization (IHLS), lecturers and ICT. The process represents the knowledge sharing activities and the output which resulted in the establishment of knowledge repository 


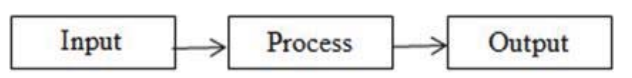

Figure 1.1: Framework Development Approach

Source: Mohd Bukhari (2010) and Fadillah (2013)

The TOE framework is used as a basis to develop a conceptual framework since it suits the factors that will be studied. Firstly, the factors that influence knowledge sharing (input); organization (IHLs), environment (lecturer), and technology (ICT) are compatible with the framework of TOE. Secondly, studies by (Zhu et al., 2002); (Lee et al., 2009) use the environmental context to potray individual. In the context of this study, lecturers represent their individual. Thirdly, TOE framework is also used to study information systems and knowledge management. In this context, the information system is in the form of repository whereas knowledge management represents knowledge sharing initiatives. There were past studies which investigate information and knowledge sharing using the TOE framework as proved by (Bigdeli et al., 2013) on information sharing and (Capestro et al., 2013) regarding knowledge sharing. Fourthly, TOE Framework is suitable to be used for research on the organization (Dwivedi et al., 2012). This is due to the formation of TOE framework is based on contingency theory which among others aimed at coordinating and planning organization activities. Lastly, the framework is also investigating the aspects on performance (Tsou \& Hsu, 2013) and innovation (Zhang \& Meng, 2009). The conceptual framework is shown in Figure 1.2 is the final form of the proposed conceptual framework of conceptual knowledge sharing initiatives.

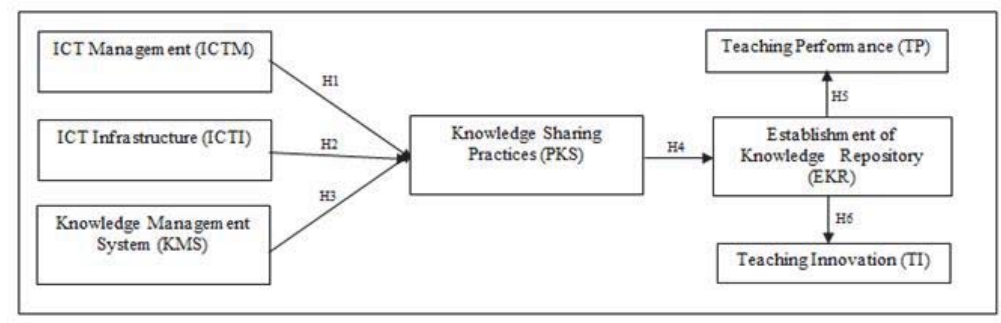

Figure 1.2: Framework for Knowledge Sharing

\section{Hypotheses}

H1: ICT Management has a positive significant to the practice of sharing knowledge among university lecturers lecturers

$\mathrm{H}$ 2: ICT infrastructure has a positive significant to the practice of sharing knowledge practices among university

H3: Knowledge Management System has a significant to knowledge sharing practices among university lecturers

$\mathrm{H} 4$ : The practices of knowledge sharing practices among lecturers have a positive significant to the establishment of repository.

$\mathrm{H} 5$ : The re-use of knowledge repositories has a positive significant to the teaching performance

H6. The re-use of knowledge repository has a positive significant to the teaching innovation

\section{Method}

This study uses a quantitative approach as it is more appropriate for researchers to understand and explain certain phenomenon (Creswell, 2009). Quantitative approach is also suitable to find out the relationship between variables. It also can explain the issue of knowledge sharing in IHL. Quantitative approach is investigative in nature, and it has a detailed technique in collecting data. The respondents of this study consisted of 150 lecturers from the Faculty of Computer in 5 universities in the Klang Valley, namely National University Malaysia (UKM), University of Malaya (UM), University of Putra Malaysia (UPM) and University of Technology Mara (UITM). Respondents were lecturers from grades 41 to JUSA C.

Data were collected using questionnaire as a data collection mechanism because it is more effective apart from 
allowing researchers to know exactly what is required and how to measure the current variables Sekaran \& Bougie, (2013). The questionnaire was constructed using Lazarsfeld Scheme technique (Lazarsfeld, 1955). Lazersfeld scheme is designed to measure the concepts in the conceptual framework (Katz \& Paul 1996). This scheme involves four stages is shown in Figure 1.3. This scheme starts from abstract concepts to the real concept. The validity of the questionnaire was tested involving experts in knowledge sharing management apart from management in itself. The pilot study was also carried out to test the consistency of the constructs item. A pilot study pointed to the reliability of the questionnaire is consistently a value between $0.8-0.9$ value of Cronbach's Alpha.

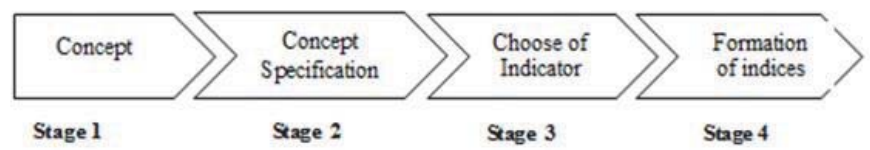

Figure 1.3: Lazarsfeld Scheme

The questionnaire consisted of 2 parts, namely close and open. The closed questionnaire came with the answer, whereas open-ended questions intended to enable the respondent to comment (Sekaran, 2010). The questionnaire contains 8 parts which were divided into 2 sections; Part A referred to Demographic Profile and Part B to Part $\mathrm{H}$ were related variables to test the hypothesis. All items in Part B - Section $\mathrm{H}$ were measured using Likert Scale of 5, 1 (Strongly Disagree) to 5 scale (Strongly Agree). Likert scale was chosen because it has several advantages such as easy to manage and use, items are easily answered by respondents and data collected has high reliability compared to other scales like Thurstone and Guttman. Data analysis using SPSS version 21.

\section{Data Analysis}

\subsection{Demographic Analysis}

Demographic analysis showed that respondents consisted of 88 (51.8\%) women and $82(48.2 \%)$ men. In terms of age, a total of $15(8.8 \%)$ respondents were between the ages of $25-30,82(48.2 \%)$ aged between $31-40$ while $58(34.1 \%)$ aged between 41 to 50 years and 15 (8.9\%) aged 50 to 60 years. As for academic qualifications of the respondents $95(55.8 \%)$ PhD holders, 72 (42.4\%) Master and 3 (1.8\%) bachelor.

\subsection{Data normality and Reliability}

Table 1.1: Data distribution and reliability

\begin{tabular}{|c|c|c|c|c|}
\hline \multirow{2}{*}{ Construct } & \multicolumn{2}{|c|}{ Data normality } & \multicolumn{2}{c|}{ Reliability } \\
\cline { 2 - 5 } & Skewness & Kurtosis & Number of item & Cronbach's Alpha \\
\hline ICTM & -0.303 & -0.172 & 4 & 0.898 \\
\hline ICTI & -0.281 & -0.122 & 4 & 0.899 \\
\hline KMS & 0.047 & -0.561 & 4 & 0.914 \\
\hline PKS & 0.206 & -0.951 & 4 & 0.860 \\
\hline EKR & -0.196 & -0.376 & 4 & 0.857 \\
\hline TP & 0.172 & -0.791 & 4 & 0.825 \\
\hline TI & -0.026 & -0.270 & 4 & 0.833 \\
\hline
\end{tabular}

The normality test was carried out to ensure the data collected were almost to normal distribution. The normal distribution of the data skewness and kurtosis were between -1 and +1 (Hair et al. 2014). This means the data distribution in this study were at normal levels. Meanwhile reliability test was conducted to assess the internal consistency of each item for the constructs (Hair et al. 2014). Cronbach alpha above 0.8 showed that reliability value is high. The summary of the reliability analysis found that all factors are consistent and reliable in this study. According to Nunnaly (1978) and Pallant (2001), Cronbach alpha coefficients above 0.7 is reliable and acceptable. It shows all the assessment criteria and the item are in questionnaire. Table 1.1 shows the Cronbach alpha, skewness and kurtosis for each construct. 


\subsection{Mean and Standard Deviation}

Table 1.2: Mean \& Standard Deviation (SD)

\begin{tabular}{|c|c|c|}
\hline Construct & Mean & Standard Deviation \\
\hline MICT & 3.79 & 0.69 \\
\hline IICT & 3.77 & 0.70 \\
\hline KMS & 4.09 & 0.65 \\
\hline PKS & 4.03 & 0.59 \\
\hline EKR & 3.96 & 0.65 \\
\hline TP & 3.95 & 0.58 \\
\hline TI & 3.80 & 0.63 \\
\hline
\end{tabular}

The 5 scales in Likert Scale, ranging from a scale of 1 (Strongly Disagree) to scale 5 (Strongly Agree) were used to measure the constructs in this study. Based on 170 respondents, the mean values were in the range of 3.77 to 4.09 and standard deviation were from 0.58 to 0.70 . Table 1.2 shows the mean and standard deviation.

\subsection{Hypothesis Testing}

Table 1.3: Correlation Analysis

\begin{tabular}{|c|c|c|c|c|c|c|c|}
\hline & ICTM & IICT & KMS & PKS & EKR & TP & TI \\
\hline ICTM & 1 & & & & & & \\
\hline ICTI & $.73^{* *}$ & 1 & & & & & \\
\hline KMS & $.57^{* *}$ & $.58^{\text {t* }}$ & 1 & & & & \\
\hline PKS & $.64^{* *}$ & $.57^{\text {th }}$ & $.71^{\star *}$ & 1 & & & \\
\hline EKR & $.73^{\text {** }}$ & $.70^{\text {t* }}$ & $.67^{* *}$ & $.65^{\text {t* }}$ & 1 & & \\
\hline TP & $.65^{* *}$ & $.71^{* *}$ & $.64^{* *}$ & $.76^{* \star}$ & $.72^{* *}$ & 1 & \\
\hline $\mathrm{TI}$ & $.70^{* *}$ & $.76^{t *}$ & $.59^{* *}$ & $.62^{* *}$ & $.70^{* *}$ & $.73^{\text {** }}$ & 1 \\
\hline
\end{tabular}

${ }^{*} p<0.01,{ }^{*} p<0.05$ :Note: All one-tailed correlations

Correlation analysis is used to find out the relationship between constructs and hypotheses. According to Hair et al. (2014), the correlation value greater than 0.90 should always be examined and if many of the correlations were above 0.80 , there is a problem with the variables. The result of analysis showed that there were no constructs that have the correlation value exceeding 0.8 . The highest correlation value is 0.76 and the lowest was 0.57 . Table 1.3 shows that all constructs have significant correlation. The hypotheses related to ICT factors, namely ICT management (ICTM), ICT infrastructure (ICTI) and Knowledge Management System (KMS) had shown significant correlation to knowledge sharing practices (KSP) among university lecturers. The study had proved that the construct on knowledge sharing practices have a significant correlation relationship to the establishment of knowledge repository (EKR). Similarly, the hypotheses re-use of knowledge repositories (EKR) have significant relationship to the teaching performance (TP) and teaching innovation (TI).

Table 1.4: Hypotheses Testing For The Research

\begin{tabular}{|c|c|c|c|}
\hline Hypothesis & Construct & Pearson product-moment correlation & Correlation \\
\hline $\mathrm{H} 1$ & $\mathrm{MICT} \rightarrow \mathrm{PKS}$ & $0.64^{\star \star}$ & Strong \\
\hline $\mathrm{H} 2$ & $\mathrm{IICT} \rightarrow \mathrm{PKS}$ & $0.57^{\star \star}$ & Strong \\
\hline $\mathrm{H} 3$ & $\mathrm{KMS} \rightarrow \mathrm{PKS}$ & $0.71^{\star \star}$ & Strong \\
\hline $\mathrm{H} 4$ & $\mathrm{PKS} \rightarrow \mathrm{EKR}$ & $0.65^{\star *}$ & Strong \\
\hline $\mathrm{H} 5$ & $\mathrm{EKR} \rightarrow \mathrm{PT}$ & $0.76^{\star \star}$ & Strong \\
\hline $\mathrm{H} 6$ & $\mathrm{EKR} \rightarrow \mathrm{IT}$ & $0.62^{\star \star}$ & Strong \\
\hline
\end{tabular}

According to Cohen (1988), the strength levels of correlation are indicated as low $(0.10 /-0.10$ to $0.29 /-0.29)$, moderate (0.3/-0.3 to 0.49/-0.49) and high (0.5/-0.5 to $1 /-1)$ Table 1.4 shows the strength levels for each linear relationship among constructs. Based on the guidelines, all the hypotheses have high value of correlation. 


\section{Conclusion}

ICT is one of the factors that can help to increase and support knowledge sharing practices among lecturers especially in Institutions of Higher Learning (IHLS). A total of six hypotheses were put to test in this study and the data analysis have proved that all hypotheses can be supported by the correlations between $0.57-0.76$. It means that ICT (ICT management, ICT infrastructure, KMS), the establishment of repository, the performance of teaching and teaching innovation have significant relationships. Apart from that, the mean values from 3.77 to 4.09 are in the range of agreed to strongly agreed. IHLs are known for knowledge-oriented institutions and practice should encourage the practice of sharing of knowledge for teaching and learning and also for researching, and this knowledge must be sustained through the establishment of repositories. The outcome of this study can serve as a guide to IHLS in designing and determining direction of ICT development towards knowledge-sharing practices, especially among lecturers for the purpose of forming a single repository thereby preserving knowledge.

\section{Acknowledgement}

The authors would like to thank the Ministry of Science Technology \& Innovation for granting this research under Fundamental Research Grant FRGS/2/2014/ICT01/UKM/01/1.

\section{References}

Agarwal, P. D., Kiran, R., \& Verma, A. K. (2012). Knowledge sharing for stimulating learning environment in institutions of higher technical education. Journal of Business Management, 6(16), 5533-5542.

Alhawary, Faleh, A., Irtaimeh, Hani, J., \& Bany Hamdan, K. (2011). Building a Knowledge Repository: Linking Jordanian Universities Elibrary in an Integrated Database System. International Journal of Business and Management, 6(4), 129-135.

Arpaci, I., Yardimci, Y. C., Ozkan, S., \& Turetken, O. (2012). ORGANIZATIONAL ADOPTION OF INFORMATION TECHNOLOGIES : A LITERATURE REVIEW. Journal of Business and Government, 4(2), 37-50.

Ayalew, E., Bekele, R., \& Straub, D. (2010). Attitude Matters: Exploring The Knowledge Sharing Behavior of Academics in Ethiopian Public Higher Education Institutions. In Proceedings of the 21st European Conference on Information Systems (pp. 1-12). Pretoria, South Africa.

Azlyn, A. Z., Zaherawati, Z., Nur Zafifa, K., Nazni, N., Mohd Zool, H. M. S., Natrah, M. J., \& Nurul Shahida, A. N. (2011). The Study of Barrier Factors in Knowledge Sharing: A Case Study in Public University. Journal of Management Science and Engineering, 5(1), 59-70.

Beatrice, B. A., Kirubakaran, E., \& Saravanan, V. (2010). Knowledge Acquisition and Storing Learning Objects for a learning repository to enhance E-learning Categories of Knowledge Learning the ontology V2-235. In 2010 2nd International Conforence on Education Technology and Computer (ICETC) (pp. 234-236). Shanghai, China.

Beyer, C. K. (2011). Assessing Facuty Excellence Through The Merit Process. Journal of Research In Innovative, 4(1).

Bigdeli, A. Z., Kamal, M., \& Cesare, S. De. (2013). Information sharing through inter-organisational systems in local government. Transforming Government: People, Process and Policy, 7(2), 148-176.

Busaidi, K. A. (2013). A Framework of Critical Factors to Knowledge Workers ' Adoption of Inter-organizational Knowledge Sharing Systems. Journal of Organizational Knowledge Management, 2013, 11.

Capestro, M., Pino, G., Peluso, A. M., \& Guido, G. (2013). Influence of Trust and Knowledge Sharing on e-Business Adoption: A Field Study in Two Italian Footwear Districts. In AIDEA 2013 Conference. Italy.

Casimir, G., Ng, Y. N. K., \& Cheng, C. L. P. (2012). Using IT to share knowledge and the TRA. Journal of Knowledge Management, 16(3), 461-479.

Cheng, J.-H., Yeh, C.-H., \& Tu, C.-W. (2008). Trust and knowledge sharing in green supply chains. Supply Chain Management: An International Journal, 13(4), 283-295.

Choubey, B. (2011). A Repository of Real-world Examples for Students and Academics. In Information Society (i-Society), 2011 International Conference on (pp. 204-207). London.

Cohen, J.W. (1988). Statistical power analysis for the behavioral sciences, Hillsdale, NJ: Lawrence Erlbaum Associates.

Creswell, J. W. (2009). Research design Qualitative, Quantitative \& Mixed Methods Approaches (3rd ed.). United States: Sage Publication.

Doctor, G., \& Ramachandran, S. (2008). DSpace@IBSA: knowledge sharing in a management institute. Vine, 38(1), 42-52.

Du, Z., Fu, X., Zhao, C., \& Liu, T. (2012). University Campus Social Network System for Knowledge Sharing. In 2012 International Conference on Systems and Informatics (ICSAI 2012) (pp. 2505-2508). Yantai, China.

Dukiü, G., \& Kozina, G. (2012). Knowledge Management in Higher Education: ICT Equipment, Skills and Attitudes of Croatian Polytechnic Students. In The ITI 201234 International Conference on Information technology Interfaces (pp. 177-182). Croatia.

Dwivedi, Y. K., Wade, M. R., \& Schneberger, S. L. (2012). Integrated Series in Information Systems Volume 28. Springer (Vol. 28).

Fadillah, Y. (2013). Kerangka Kerja Penggalakan ICT Dalam Perkongsian Pengetahuan Dalam Kalangan Guru di Malaysia. Universiti 
Kebangsaan Malaysia.

Hafiza, A., \& Dang, M. H. (2012). Communication Technology on Academician ' s Knowledge Sharing Behavior at Private University. In IEEE Colloquium on Humanities, Science \& Engineering Research (CHUSER 2012) (pp. 593-597). Sabah.

Han, B. M., \& Anantatmula, V. S. (2007). Knowledge sharing in large IT organizations: a case study. Vine, 37(4), 421-439.

Hannay, L. (2013). A case study of district leadership using knowledge management for educational change. Journal of Organizational Change Management, 26(1), 64-82.

Howell, K. E., \& Annansingh, F. (2013). Knowledge generation and sharing in UK universities: A tale of two cultures? International Journal of Information Management, 33(1), 32-39.

Iqbal, M. J., Rasli, A., Heng, L. H., Bin, M., Ali, B., Hassan, I., \& Jolaee, A. (2011). Academic staff knowledge sharing intentions and university innovation capability. African Journal of Business Management, 5(27), 11051-11059.

Islam, M. a., Ikeda, M., \& Islam, M. M. (2013). Knowledge sharing behaviour influences: A study of Information Science and Library Management faculties in Bangladesh. IFLA Journal, 39(3), 221-234.

Kiran, R., Agarwal, P. D., \& Verma, a. K. (2013). Knowledge Management: Role of Thought Leaders and Junior Academia in Enhancing Research and Curriculum in Institutions of Higher Technical Education. SAGE Open, 3(2).

Kumar, N., \& Rose, R. C. (2012). The impact of knowledge sharing and Islamic work ethic on innovation capability. Cross Cultural Management: An International Journal, 19(2), 142-165.

Lee, O.K., Wang, M. W., \& Lim, K. H. (2009). Knowledge Management Systems Diffusion in Chinese Enterprises: A Multistage Approach Using Environment Framework. Journal of Global Information Management (JGIM), 17(1), 70-84.

Li, X., Roberts, J., Yan, Y., \& Tan, H. (2013, August). Knowledge sharing in China-UK Higher Education Alliances. International Business Review, pp. 1-13. Elsevier Ltd.

Lippert, S. K., \& Ph, D. (2006). Technological, Organizational, and Environmental Antecedents to Web Services Adoption. Communications of the IIMA, 6(1).

Mohd Bakhari, I. (2010). Model Kualiti Perkongsian Dalam Organisasi Awam dan Kesannya ke Atas Prestasi Pekerja Serta Penyampaian Perkhidmatan. PhD. Thesis. Universiti Kebangsaan Malaysia.

Naiwen, L., \& Xin, Z. (2012). The Study on Constructing Institutional Repository of University. In 2012 Fourth International Conference on Multimedia Information Networking and Security (pp. 689-692). Nanjing, China.

Nesheim, T., \& Gressgård, L. J. (2014). Knowledge sharing in a complex organization: Antecedents and safety effects. Safety Science, $62,28-36$.

Nistor, N., Baltes, B., \& Schustek, M. (2012). Knowledge sharing and educational technology acceptance in online academic communities of practice. Campus-Wide Information Systems, 29(2), 108-116.

Nonaka, I. (2006). Organizational Knowledge Creation Theory: Evolutionary Paths and Future Advances. Organization Studies ,Vol. 27, 1179-1208.

Noor Hisham, M. N. (2011). Pengajaran dan pembelajaran: Penelitian Semula Konsep-Konsep Asas Menurut Perspektif Gagasan Islamisai IImu Moden. In Kongres Pengajaran dan Pembelajaran UKM 2011 (pp. 1-15). Bangi, Malaysia.

Noorazah, M. N. (2013). Model Perkongsian Pengetahuan Dalam Sektor Swsata di Malaysia. Universiti Kebangsaan Malaysia.

Nor Ashmiza, M. I. (2012). Key Determinants of Research Knowledge Sharing in UK Higher Education Institution. Ph.D Thesis. University of Portsmouth.

Norashikin, U. (2013). Model Penilaian Pengurusan Skop Projek Teknologi Maklumat dan Komunikasi (ICT) Sektor Awam. UKM.

Nunnaly, J (1978). Psychometric Theory. New York: McGraw-Hill.

Oliveira, T., Martins, M. F., \& Lisboa, U. N. De. (2011). Literature Review of Information Technology Adoption Models at Firm Level. The Electronic Journal Information Systems Evaluation, 14(1), 110-121.

Pallant, J. (2001), SPSS Survival Manual, Allen \& Unwin, Crows Nest.

Patel, M., \& Ragsdell, G. (2011). To Share or Not to Share Knowledge: An Ethical Dilemma for UK Academics?, Journal of Knowledge Management Practice, 12(2).

Raab, K. J., Ambos, B., \& Tallman, S. (2014). Strong or invisible hands? - Managerial involvement in the knowledge sharing process of globally dispersed knowledge groups. Journal of World Business, 49(1), 32-41.

Radovanović, D., Šarac, M., Adamović, S., \& Lučić, D. (2011). Necessity of IT Service Management and IT Governance. In MIPRO 2011 (pp. 1430-1433). Opatija, Croatia.

Rahab, \& Wahyuni, P. (2013). Predicting Knowledge Sharing Intention Based on Theory of Reasoned Action Framework : An Empirical Study on Higher Education Institution. American International Journal of Contemporary Research, 3(1), 138-147.

Savita, K. S, Dominic, P. D. ., \& Ramayah, T. (2012). Eco-Design Strategy among ISO 14001 Certified Manufacturing Firms in Malaysia : Green Drivers and Its Relationship to Performance Outcomes. In 2012 International Conference on Computer \& Information Science (ICCIS) (pp. 154-159). Kuala Lumpur.

Sekaran, U., \& Bougie, R. (2013). Research Methods for Business: A Skill-Building Approach, (6th Editio.). John Wiley and Sons.

Shah, R. A. W., Roziana, S., Nor Akmar, N., Azizah, R., \& Khairunesa, I. (2009). Faktor Persekitaran Organisasi Mempengaruhi Perkongsian Pengetahuan: Satu Analisis di Institut Kemahiran MARA Johor. In Amalan Latihan \& Pembangunan Sumber Manusia di Malaysia (pp. 218-236). Johar Bharu: UTM: Penerbit UTM Press.

Sulisworo, D. (2012). Enabling ICT and Knowledge Management to Enhance Competitiveness of Higher Education Institutions. International Journal of Education, 4(1), 112-121.

Tornatzky, L. \& Fleischer, M. (1990). The Processes of Technological Innovation. Lexington, MA: Lexington Books. 
Tsou, H.-T., \& Hsu, S. H.-Y. (2013). Assessing the Importance of TOE Openness for Firm Performance: Does Co-Production Matter? In The 2013 International DSI and Asia Pacific DSI Conference. Bali, Indonesia.

Tung, T., \& Lai, W. (2013). The Key Factors Affecting Business Model for Enterprises Adopting Cloud Computing Technology. In Business and Information 2013 (Vol. 2013, pp. 386-425). Bali, Indonesia.

Wang, D. (2009). On Teaching Innovation of the Course. In First International Workshop on Education Technology and Computer Science (pp. 919-922). Wuhan, TBD, China.

Yahya, B., \& Lailinanita, A. (2012). Inovasi Pengajaran Dan Pembelajaran Dalam Kalangan Guru-Guru Teknikal Di Sekolah Menengah Teknik Dari. Journal of Technical, Vocational \& Engineering Education, 6, 44-58.

Zhang, N., \& Meng, Q. (2009). Innovation 2 . 0 as a Paradigm Shift : Comparative Analysis of Three Innovation Modes. In International Conference on. IEEE Management and Service Science, 2009. MASS'09 (pp. 1-5). Chicago.

Zheng, Z. (2012). The design of technical system for software project team sharing knowledge. In 2012 24th Chinese Control and Decision Conference (CCDC) (pp. 2667-2671). China.

Zhu, K., Kraemer, K. L., \& Xu, S. (2002). A Cross-Country Study of Electronic Business Adoption Using the Technology-OrganizationEnvironment Framework. In Twenty-Third International Conference on Information Systems (pp. 337-348). Chicago. 